\title{
ANALISIS LOYALITAS KERJA PEGAWAI DINAS PENDIDIKAN KABUPATEN LABUHANBATU
}

\author{
Novrihan Leily Nasution \\ Prodi Manajemen, Fakultas Ekonomi Universitas Al Washliyah Labuhanbatu \\ E-mail : novrih4n.leily@gmail.com
}

\begin{abstract}
ABSTRAK
Penelitian ini bertujuan untuk menganalisis loyalitas kerja pegawai Dinas Pendidikan Kabupaten Labuhanbatu yang dapat dilihat dari sumber daya manusianya dan juga sistem kerjanya. Metode yang digunakan dalam peneleitian ini adalah metode analisis deskriptif. Sedangkan variabel peelitian adalah loyalitas kerja pegawai Dinas Pendidikan Kabupaten Labuhanbatu.

Berdasarkan hasil penelitian ini dapat disimpulkan bahwa loyalitas kerja pegawai Dinas Pendidikan Kabupaten Labuhanbatu berjalan dengan baik sesuai dengan tugas dan tanggung jawab bagian masing-masing pegawai Dinas Pendidikan Kabupaten Labuhanbatu. Penelitian menganalisis loyalitas kerja pegawai Dinas Pendidikan Kabupaten Labuhanbatu berdasarkan kedekatan dan keakraban pimpinan dengan pegawai dan staf di Dinas Pendidikan Kabupaten Labuhanbatu. Aspek-apek loyalitas kerja pegawai Dinas Pendidikan Kabupaten Labuhanbatu yang terdapat pada pegawai anatara lain: 1). Taat pada peraturan, 2). Tanggung jawab pada kantor Dinas Pendidikan Kabupaten Labuhanbatu, 3). Kemauan untuk bekerjasama, 4). Rasa memiliki, 5). Hubungan antar pribadi, 6). Kesukaan terhadap pekerjaan. Melihat loyalitas kerja pegawai Dinas Pendidikan Kabupaten Labuhanbatu dapat diketahui bahwa kinerja dari pegawai Dinas Pendidikan Kabupaten Labuhanbatu dapat dilihat dari kebijakan-kebijakan yang dibuat oleh kepala Dinas Pendidikan Kabupaten Labuhanbatu.
\end{abstract}

\section{Kata Kunci: Loyalitas Kerja Pegawai, Kantor Dinas Pendidikan.}

\section{A. Latar belakang}

Kedudukan dan peranan pegawai Negeri Sipil sebagai unsur aparatur Negara yang bertugas sebagai abdi masyarakat haruslah menyelenggarakan pelayanan secara adil kepada masyarakat dengan dilandasi kesetian dan ketaatan kepada Pancasila dan Undang-undang Dasar 1945. Untuk dapat melaksanakan tugas-tugas dengan baik. Maka pembinaan pegawai dalam sebuah instansi pemerintahan terutama pada Dinas Pendidikan Kab.Labuhanbatu maka pembinaan pegawai sangatlah penting untuk meningkatlan kualitas sumber daya manusia agar memiliki sikap dan prilaku yang berintikan pengabdian, Kejujuran, tanggung jawab, Serta wibawa sehingga dapat memeberikan pelayanan sesuai wibawa sehingga dapat memberikan pelayanan sesuai tuntutan perkembangan masyarakat, Mengingat pentingnya masalah kesetiaan pegawai yang belum semuanya merata. 
Loyalitas berasal dari kata loyal yang berarti setia. Loyalitas dalam Kantor dapat diartikan sebagai kesetiaan seorang pegawai terhadap Kantor. Velasques dalam Sudimin (2003) mengatakan bahwa kewajiban pegawai adalah bekerja dengan baik untuk mencapai tujuan Kantor Dinas Pendidikan dan menghindari aktivitas yang dapat mengancam atau mengganggu pencapaian tujuan tersebut dan bukan untuk kepentingan atau manfaat pribadi pegawai. Hal yang bisa menimbulkan kesulitan terhadap terwujudnya loyalitas adalah konflik kepentingan (conflict of interest), yaitu konflik antara kepentingan pribadi pegawai dan kepentingan Kantor. Demi kepentingan pribadi, pegawai tidak boleh melanggar aturan yang sudah ditetapkan di Dinas Pendidikan Kab.Labuhanbatu. Selain itu, konflik kepentingan juga bisa muncul dengan terjadinya penggabungan beberapa jenis pekerjaan.

Meningkatkan loyalitas dan prestasi kerja pegawai, pihak Kepala dinas harus dapat menciptakan program pemeliharaan pegawai, yang salah satunya dengan menerapkan sistem insentif (tunjangan) yang tepat. Menurut Dessler (2005) semua rencana insentif secara tradisional adalah rencana pembayaran untuk kinerja pegawai Dinas pendidikan .Arep dan Tanjung (2002) berpendapat bahwa tidak hanya pemberian insentif berbentuk fisik seperti uang saja yang dapat memotivasi karyawan, melainkan insentif positif yang dapat memuaskan kebutuhan non fisik seperti kebutuhan emosi dan intelektual juga harus diperhatikan. Siagian (2004) juga berpendapat bahwa untuk lebih mendorong produktivitas kerja yang lebih tinggi, banyak kantor yang menganut sistem insentif sebagai bagian dari sistem imbalan yang berlaku bagi para pegawai kantor.

Menurut Hasibuan (2007) insentif dapat diberikan sebagai bentuk non material insentif, dimana non material insentif adalah daya perangsang yang diberikan kepada pegawai berbentukpenghargaan atau pengukuhan berdasarkan prestasi kerjanya, seperti piagam, piala, atau medali.

Rendahnya kualitas sumber daya manusia merupakan masalah mendasar yang dapat menghambat pembangunan dan perkembangan ekonomi nasional. Rendahnya kulitas sumber daya manusia juga akan menjadi batu sandungan dalam era globalisasi, karena era globalisasi merupakan era persimpangan mutu. Jika bangsa Indonesia ingin berkiprah dalam percaturan global, maka langkah pertama yang harus dilakukan adalah menata sumber daya manusia, baik dari aspek intelektual, spiritual, kreativitas, moral, maupun tanggung jawab. Kualitas sumber daya manusia sangat erat kaitannya dengan kinerja ( performance). 
Sebagai unsur aparatur pemerintah, pegawai sekaligus sebagai abdi Negaradan abdi masyarakat mempunyai peranan yang sangat penting, yaitu sebagai pemikir, perencana, penggerak partisipasi masyarakat dalam proses pembangunan, menjaga persatuan dan kesatuan bangsa dengan penuh kesetiaan kepada pancasila dan Undang-Undang Dasar 1945 serta sekaligus berperan sebagai pengendali dan pengawas pelaksanaan pembangunan itu sendiri. Dalam hal ini sangat jelas bahwa kedudukan dan peranan pegawai negeri sangat penting, sebagai mana dikemukakan didalam Undang-Undang Kepegawaian No. 43 Tahun1999 tentang Pokok-Pokok Kepegawaian bahwa dalam rangka usaha mencapai tujuan nasional untuk mewujudkan masyarakat madani yang taat hukum,berperadaban modern, demokratis, makmur, adil, dan bermoral tinggi, diperlukan Pegawai Negeri yang merupakan unsure aparatur negara yang bertugas sebagai abdi masyarakat yang menyelenggarakan pelayanan secara adil dan merata.

\section{Ciri-ciri Loyalitas}

Penjabaran sikap setia kepada Kantor, menurut Poerwopoespito(2000), antara lain adalah

a. Kejujuran

Kejujuran mempunyai banyak dimensi dan bidang. Dalam konteks sikap setia kepada setiap instansi. Ketidak jujuran di kantor akan merugikan banyak orang dan masyarakat.

b. Mempunyai rasa memiliki terhadap kantor

Memberi pengertian agar Pegawai/staf mempunyai rasa memiliki terhadap kantor adalah dengan memahami bahwa Kantor adalah tubuh imajiner, dimana seluruh yang terlibat di dalamnya merupakan anggota-anggotanya

c. Mengerti kesulitan Kantor

Memahami bahwa yang terbaikuntuk Kantor pada hakikatnya terbaik untuk Pegawai. Dan terbaik untuk pegawai belum tentu terbaik untuk Kantor. Tindakan yang bijak yang dilakukan oleh pegawai dan staf dalam memahami dan mengerti kesulitan Kantor adalah dengan saling bahumembahu untuk membantu pulihnya Kantor bukan dengan meninggalkannya dan segera pindah ke Kantor yang lain. 


\section{B. Permasalahan}

Untuk mempermudah pemahaman terhadap permasalahan dalam penelitian ini, maka penulis merumuskan permasalahan sebagai berikut: Analisis Loyalitas Kerja Pegawai Dinas Pendidikan Kabupaten Labuhanbatu

\section{Kajian teori}

Manajemen Sumber Daya Manusia Perusahaan merupakan suatu organisasi yang bergerak pada bidang tertentu, dengan tujuan mendapatkan keuntungan. Keberhasilan suatu perusahaan sangat ditentukan oleh kemampuan perusahaan dalam mengatur pemanfaatan sumberdaya manusia (SDM) dan sumber-sumber daya lainnya secara efektif dan efisien, guna mencapai tujuan perusahaan tersebut. Mengingat pentingnya peranan manusia dalam kegiatan suatu perusahaan, maka diperlukan suatu ilmu dan seni yang mampu mengatur pemanfaatan SDM dalam suatu perusahaan. Ilmu dan seni yang dimaksud tersebut adalah manajemen sumber daya manusia (MSDM).

Menurut Drs.Malayu S.P. Hasibuan MSDM adalah ilmu dan seni mengatur hubungan dan peranan tenaga kerja agar efektif dan efisien membantu terwujudnya tujuan prusahaan, Karyawan, dan masyarakat.

Menurut Edwin B. Flippo "Personnel management is the planning, Organizing, directing and controlling of the procurement, development, compensation, integration, maintenance, and societal objectives are accomplished. (Manajemen personalia adalah perencanaan, perorganisasian, pengarahan, dan pengendalian dari pengadaan, pengembangan, Kompensasi, Pengintegrasian, Pemeliharaan, dan pemberhentian karyawan, dengan maksud terwujudnya tujuan prusahaan, individu, karyawan dan masyarakat).

Hasibuan (2007), menyatakan bahwa MSDM adalah ilmu dan seni yang mengatur hubungan dan peranan tenaga kerja agar efektif dan efisien membantu terwujudnya tujuan perusahaan, karyawan dan masyarakat. Karyawan bertujuan mendapatkan kepuasan dari pekerjaannya. Masyarakat bertujuan mendapatkan barang/jasa yang baik dengan harga yang wajar dan selalu tersedia di pasar, sedangkan pemerintah mengharapkan selalu mendapatkan pajak. MSDM adalah perusahaan. Dengan demikian, fokus MSDM ialah masalah yang berhubungan dengan tenaga kerja manusia. Menurut Kiggundu dalam Gomes (2003), MSDM merupakan pengembangan dan pemanfaatan karyawan bagi pencapaian yang efektif mengenai sasaran-sasaran dan tujuan-tujuan individu, organisasi dan masyarakat. 


\section{Loyalitas Pegawai}

Dalam melaksanakan kegiatan kerja, pegawai tidak akan terlepas dari loyalitas dan sikap kerja sehingga dengan demikian pegawai tersebut akan selalu melaksanakan pekerjaan dengan baik. pegawai merasakan adanya kesenangan yang mendalam terhadap pekerjaan yang di lakukan. Tommy dkk. 2010: 16.Loyalitas kepada pekerjaan tercermin pada sikap pegawai yang mencurahkan kemampuan dan keahlian yang di miliki, melaksakan tugaas dengan tanggung jawab, jujur dalam bekerja, hubungan kerja yang baik dengan atasan, kerja sama yang baik dengan rekan kerja, disiplin, menjaga citra Kantor, dan adanya kesstiaan untuk bekerja dalam waktu lebih panjang.

Loyalitas merupakan sikap kesetiaan yang ditunjukkan oleh seseorang melalui pelayanan maupun tanggung jawab dengan perilaku yang baik. Dalam melaksanakan kegiatan kerja pegawai tidak akan terlepas dari loyalitas dan sikap kerja, sehingga dengan demikian pegawai tersebut akan selalu melaksanakan pekerjaan dengan baik. pegawai merasakan adanya kesenangan yang mendalam loyalitas para pegawai dalm suatu organisasi itu mutlak diperlukan demi kesuksesan organisasi itu sendiri. Semangkin tinggi loyalitas para pegawai disuatu organisasi yang di tetapkan sebelumnya oleh pemilik organisasi.

Sedangkan sebaliknya, bagi organisasi loyalitas para pegawainya renda, maka semakin sulit bagi organisasi tersebut untuk mencapai tujuantujuanorganisasinya yang telah ditetapkan sebelumnya oleh para pemilik organisasi (Soegandhi et al,2013: 3). Tingkat turn over yang tinggi di sebuah perusahaan bisa menggambarkan rendahnya tingkat loyalitas para pekerja terhadap kantoritu. Loyalitas yang rendah tentu saja yang merupakan penyakit serius yang dapat menghambat kemajuan sebuah kantor . Kondisi itu saja tidak boleh di biarkan berlalutlalut dan menjadi duri dalam daging di lingkungan kerja (Marpaung, 2012: 685).

Menurut Danim (dalm Prayanto, 2008: 23) mengatakan bahwa ciri-ciri pegawai yang loyal adalah:

1. Bertanggung jawab, artinya mampu mengemban tugas dengan benar, berani mengambil resiko apapun yang di lakukan akan dipertanggung jawabkan walaupun menyakitkan

2. Mau berkorban untuk kepentingan bersama atau organisasi yang harus di perjuangkan bersama.

3. Berani menjadi dirinya sendiri, memiliki sikap percaya diri yang tinggi, mampu menyelesaikan masalah-masalah yang dihadapinya. 
4. Selalu melibatkan diri setiap kegiatan yang diselenggaran organisasi.

5. Pegawai/staf senantiasa menerima dengan lapang dada dan kritik membangun yang disampaikan oleh pimpinannya maupun pegawai yang lain

\section{Fungsi-fungsi Manajemen Sumber Daya Manusia.}

Manusia merupakan faktor penggerak organisasi dalam mencapai tujuan organisasi, dimana manusia yang mengambil keputusan dalam menjalankan suatu organisasi. Dalam mengelola unsur manusia secara baik, agar diperoleh tenaga kerja yang loyal terhadap pekerjaanya, diperlukan fungsi-fungsi MSDM. Arep dan Tanjung (2002) membedakan fungsifungsi MSDM atas fungsi manajerial dan fungsi operasional sebagai berikut:

1. Fungsi Manajerial adalah fungsi manajemen yang berkaitan langsung dengan aspek-aspek manajerial, termasuk dalam fungsi ini adalah:

2. Fungsi perencanaan, yaitu melaksanakan tugas dalam merencanakan kebutuhan, pengadaan dan kebutuhan serta pemeliharaan SDM.

3. Fungsi pengorganisasian, yaitu menyusun suatu organisasi dengan membentuk struktur hubungan antara tugas yang harus dikerjakan oleh tenaga kerja yang dipersiapkan.

4. Fungsi pengarahan, yaitu memberi dorongan untuk menciptakan kemauan kerja yang dilaksanakan secara efektif dan efisien.

5. Fungsi pengendalian, yaitu melakukan pengukuran antara kegiatan yang telah dilakukan dengan standar yang telah diterapkan, khususnya di bidang tenaga kerja. Pemeliharaan hubungan yang berkelanjutan dan serasi dengan pegawai dalam setiap instansi menjadi sangat penting (Siagian, 2004). Menurut Robbins dalam Arep dan Tanjung (2002) pemeliharaan adalah melaksanakan program-program tertentu atau membuat kebijakankebijakan khusus agar tenaga kerja dapat terpelihara dengan baik. Sedangkan, Zainun (2001) mendefinisikan pemeliharaan sebagai suatu upaya yang dilakukan oleh Kantor Dinas Pendidikan dalam menyediakan dan memberikan ganjaran berupa finansial maupun material kepada seluruh SDM dari tingkat tertinggi sampai tingkat paling rendah. Pemeliharaan merupakan cara bagaimana memelihara tenaga kerja yang telah diterima bekerja agar tatap loyal terhadap kantor Dinas

Pendidikan (Cascio dalam Arep dan Tanjung, 2002). Kemudian, Flippo (1996) mengartikan pemeliharaan sebagai upaya untuk memelihara tenaga kerja agar tetap betah 
bekerja dan memiliki kemauan untuk melaksanakan tugas-tugas yang diberikan terhadap Kepala Dinas Pendidikan.Dengan demikian, fokus

MSDM ialah masalah yang berhubungan dengan tenaga kerja manusia. Menurut Kiggundu dalam Gomes (2003), MSDM merupakan pengembangan dan pemanfaatan pegawai bagi pencapaian yang efektif mengenai sasaran-sasaran dan tujuantujuan individu, organisasi dan masyarakat.

Hasibuan (2007) mendefinisikan pemeliharaan (maintenance) pegawai merupakan usaha mempertahankan dan atau meningkatkan kondisi fisik, mental dan sikap pegawai, agar mereka tetap loyal dan bekerja produktif untuk menunjang tercapainya tujuan Adapun fungsi dari pemeliharaan pegawai adalah menyangkut perlindungan kondisi fisik, mental dan emosi pegawai. Oleh karena itu, keamanan dan kesehatan kerja pegawai perlu mendapat pemeliharaan sebaik-baiknya dariKepala Dinas Pendidikan (Flippo dalam Hasibuan, 2007).

\section{Tujuan Pemeliharaan pegawai}

Tujuan utama melakukan program pemeliharaan pegawai adalah untuk membuat setiap orang dalam setiap instansi merasa betah dan senantiasa bertahan sekalipun terjadi hal-hal yang dapat mengganggu kestabilan dan keadaan Kantor (Zainun,2001). Kemudian, Siagian(2004) berpendapat bahwa tujuan penerapan pemeliharaan pegawai merupakan upaya untuk mewujudkan pengakuan dan penghargaan atas harkat dan martabat manusia, sehingga mereka bahagia dalam melakukan pekerjaannya yang pada akhirnya akan berimplikasi pada peningkatan produktivitas pegawai.

Adapun tujuan pemeliharaan pegawai menurut Hasibuan (2007), antara lain:

1. Meningkatkan produktivitas kerja pegawai.

2. Meningkatkan disiplin dan menurunkan absensi pegawai.

3. Meningkatkan loyalitas dan menurunkan turnover pegawai.

4. Memberikan ketenangan, keamanan dan kesehatan pegawai.

5. Meningkatkan kesejahteraan pegawai dan keluarganya.

6. Memperbaiki kondisi fisik, mental dan sikap pegawai.

7. Mengurangi konflik serta menciptakan suasana yang harmonis.

8. Mengefektifkan pengadaan pegawai. 
Menurut Flippo (1996), metode pemeliharaan pegawai secara khususadalah sebagai berikut:

1. Sikap ,Jumlah faktor yang mempengaruhi pengembangan dan pemeliharaan sikap pegawai tidak terbatas,tetapi proses-proses komunikasi verbal dan non verbal terlibat dalam setiap tahap.

2. Keadaan Jasmani, Pemeliharaan keadaan jasmani yang dimaksud dapat dilakukan dengan penerapan kesehatan dan keselamatan kerja yang dilakukan.

Beberapa metode pemeliharaan pegawai menurut Hasibuan (2007) antara lain:

1. Komunikasi yang efektif;

2. Pemberian insentif;

3. Peningkatan kesejahteraanpegawai;

\section{D.Hasil dan Pembahasan}

Untuk mengetahui apakah seorang karyawan loyal terhadapkantor Dinas Pendidikan kabupaten Labuhanbatu. Terdapat beberapa aspek yang dapat digunakan oleh perusahaan untuk mengukur loyalitas pegawai tersebut. Aspek-aspek loyalitas kerja pegawai di Dinas Pendidikan Kabupaten Labuhanbatu yang terdapat pada seorang karyawan antara lain:

1. Taat Pada Peraturan.

Pegawai yang bekerja di Dinas Pendidikan Kabupaten Labuhanbatu dikatakan loyal jika akan selalu taat pada peraturan.Sesuai dengan pengertian loyalitas, ketaatan ini timbul dari kesadaran pegawai jika peraturan yang dibuat oleh Kantor sematamata disusun untuk memperlancar jalannya pelaksaan kerja di setiap instansi.

Kesadaran ini membuat pegawaiakan bersikap taat tanpa merasa terpaksa atau takut terhadap sanksi yang akan diterimanya apabila melanggar peraturan tersebut.

2. Tanggung jawab pada perusahaan/organisasi.

Pegawai yang bekerja di Dinas pendidikan kabupaten Labuhanbatu sudah dikatakan bertanggung jawab dalam melaksanakan tugas-tugas yang diberikan kepada kepala Dinas Pendidikan Kabupaten Labuhanbatu dengan melayani masyarakat dengan baik dan sopan. Pegawai di Dinas Pendidikan memiliki sikap sesuai dengan pengertian loyalitas, pegawaiakan berhati-hati dalam mengerjakan tugas-tugasnya, namun sekaligus berani untuk mengembangkan berbagai inovasi demi kepentingan Kantor 


\section{Kemauan untuk bekerja sama.}

Pegawai di Dinas pendidikan kabupaten Labuhanbatu memiliki sikap sesuai dengan loyalitas, Mampu bekerja sama dengan pegawai lain. Bekerja sama dengan orang lain dalam suatu pekerjaan yang ada di setiap instansi dan mampu mewujudkan mewujudkanvisi dan misi kantor Dinas Pendidikan untuk dapat mencapai tujuan yang tidak mungkin dicapai oleh seorang pegawaisecara invidual.

\section{Rasa memiliki}

Pegawai di Dinas Pendidikan Kabupaten Labuhanbatu mempunyai rasa ikut memiliki terhadap Kantor Dinas Pendidikan.

\section{Hubungan antar pribadi}

Pegawai di Dinas Pendidikan Kabupaten Labuhanbatu memiliki loyalitas kerja tinggi antar pribadi yang baik terhadap pegawai lain dan juga terhadap atasannya. Sesuai dengan pengertian loyalitas, hubungan antar pribadi ini meliputi hubungan sosial dalam pergaulan sehari-hari, baik yang menyangkut hubungan kerja maupun kehidupan pribadi.

6. Kesukaan terhadap pekerjaan Sebagai manusia, pegawai pasti akan mengalami masa-masa jenuh terhadap pekerjaan yang dilakukannya setiap hari. Seorang pegawai yang memiliki sikap sesuai dengan pengertian loyalitas akan mampu menghadapi permasalahan ini dengan bijaksana. Hal ini hanya dapat dilakukan apabila seorang pegawai/staf mencintai pekerjaannya.

\section{Penyebab Turunnya Loyalitas Pegawai}

Seperti yang telah dijabarkan pada awal tulisan, pengertian loyalitas adalah suatu hal yang sulit untuk diciptakan namun mudah untuk dihilangkan. Seorang pegawai yang baru masuk dalam sebuah perusahaan memerlukan waktu untuk dapat menjadi loyal sesuai dengan pengertian loyalitas. Akan tetapi, sikap loyal yang sesuai dengan pengertian loyalitas tersebut dapat tiba-tiba hilang apabila seorang pegawai merasa "dikecewakan". Setidaknya terdapat tiga faktor yang dapat menjadi penyebab turunnya loyalitas pegawai sesuai dengan pengertian loyalitas, yakni:

\section{Faktor rasional}

Faktor rasional turunnya loyalitas pegawai mengacu pada hal-hal yang dapat dijelaskan secara logis. Faktorfaktor rasional yang menjadi penyebab turunnya loyalitas pegawaisesuai dengan pengertian loyalitas antara lain gaji, bonus, jenjang karir, dan fasilitas-fasilitas yang diberikan Kantor kepadapegawai. 


\section{Faktor emosional}

Faktor emosional turunnya loyalitas pegawai mengacu pada hal-hal yang menyangkut perasaan atau ekspresi diri. Faktor-faktor emosional yang menjadi penyebab turunnya loyalitas pegawaisesuai dengan pengertian loyalitas antara lain pekerjaan yang dinilai kurang menantang, lingkungan kerja yang tidak kondusif, perasaan was-was terhadap keberlangsungan hidup kantor, ketidakcocokan pegawaidenganpemimipin, pekerjaan yang dinilai tidak prestige, serta kurangnya penghargaan terhadap prestasi kerja pegawai.

3. Faktor kepribadian

Faktor kepribadian sebagai penyebab turunnya loyalitas pegawai mengacu pada hal-hal yang sifat pribadi pegawai. Faktor-faktor kepribadian yang menjadi penyebab turunnya loyalitas pegawai sesuai dengan pengertian loyalitas antara lain adalah sifat mudah bosan dan ketidakcocokan pegawai dengan budaya kerja.

\section{Motivasi}

Motivasi Di Dinas Pendidikan, Menurut G.R.Terry mengemukakan bahwa motivasi adalah keinginan yang terdapat pada diri seseorang individu yang merangsangnya untuk melakukan tindakan-tindakan. Pengaruh Motivasi Terhadap Komitmen, Hasil olah data dengan Dinas pendidikan tanggapan yang diberikan responden menunjukkan adanya pengaruh positif antara motivasi (Sungguh-sungguh dalam menyelesaikan pekerjaan dan berani berkorban, Tanggung jawab dalam bekerja, serta Sikap ulet, tabah, jujur dan konsisten dalam bekerja) terhadap komitmen. Ini berarti bahwa semakin tinggi atau semakin kuat motivasi, maka komitmen Kerja Dinas Pendidikan juga akan meningkat.

\section{Disiplin}

Disiplin pada Dinas Pendidikan ini adalah pelatihan yang mengarah pada upaya membenarkan danmelibatkan pengetahuan-pengetahuan sikap dan perilaku pegawai sehingga ada kemauanpada diri pegawai untuk menuju pada kerjasama dan prestasi yang lebih baik”.Pengaruh Disiplin Terhadap Kinerja Dinas PendidikanHasil penelitian ini menunjukkan bahwa disiplin mempunyai pengaruh positif terhadap kinerja sumber daya manusia, artinya semakin tinggi disiplin pegawai kepada organisasi akan meningkatkan kinerja sumber daya manusia. Hal ini berarti jika disiplin pegawai meningkat maka kinerja Dinas Pendidikan juga akan meningkat atau dapat dikatakan bahwa semakin tinggi disiplin pegawai maka semakin tinggi kinerja Dinas Pendidikan. 


\section{Lingkungan Kerja}

Lingkungan kerja Di Dinas Pendidikan merupakan salah satu faktor yang dapat mempengaruhi produktivitas kerja dan efektivitas kerja pegawai. Yang bentuknya dapat berupa lingkungan materiil, serta lingkungan psikologis seperti suasanahubungan social antar personal Kantor. Adapun indikatornya ialah : hubungan antar pegawai, suasana kerja, dan fasilitasfasilitas kerja pegawai. Pengaruh Lingkungan Kerja Terhadap Kinerja Dinas Pendidikan Hasil penelitian ini menunjukkan bahwa lingkungan kerja mempunyai pengaruhpositif terhadap kinerja sumber daya manusia, artinya lingkungan kerja semakin kondusif akan meningkatkan kinerja di Dinas Pendidikan Labuhanbatu, Hal inimenunjukkan bahwa lingkungan kerja mampu meningkatkan kinerja sumber daya manusia.

\section{Komitmen}

Komitmen yang berada di Dinas Pendidikan, Sebagai definisi yang umum, Luthans (1995) mengartikan komitmen organisasional merupakan sikap yang menunjukkan loyalitas pegawai dan merupakan proses berkelanjutan bagaimana seorang anggota organisasi mengekspresikan perhatian mereka kepada kesuksesan dan kebaikan organisasinya. Adapun indikatornya ialah : memiliki hasrat, memiliki kemauan, dan memiliki ikatan emosional. Keberhasilan pengelolaan organisasi sangatlah ditentukanoleh keberhasilan dalam mengelola SDM. Pengaruh Komitmen Terhadap Kinerja Dinas Pendidikan Hasil penelitian ini menunjukkan bahwa komitmen (Memiliki hasrat, Memiliki kemauan, serta Memiliki ikatan emosional) mempunyai pengaruh positif terhadap kinerja sumber daya manusia, artinya dengan adanya komitmen yang tinggi maka akan meningkatkan kinerja di Dinas Pendidikan Kab.Labuahanbatu

\section{E.Kesimpulan \& Saran}

\section{Kesimpulan}

1. Analisis loyalitas kerja pegawai dapat disimpulkan bahwa loyalitas salah satu yang tidak dapat dibeli dengan uang. Loyalitas hanya bisa di dapatkan, namun tidak bisa dibeli. 
2. Mendapatkan loyalitas dari seseorang bukanlah sesuatu pekerjaan yang mudah untuk dilakukan.berbanding terbalik dengan kesulitan mendapatkannya, menghilangkan loyalitas seseorang justru menjadi hal yang sangat mudah untuk dilakukan.

3. Pemeliharaan pegawai merupakan salah satu fungsi dari MSDM, Yaitu fungsi oprasional dimana dalam fungsi oprasional terdapat pemeliharaan yang berarti memelihara tenaga tenaga kerja agar betah bekerja di setiap instansi tersebut.

4. Pemeliharaan pegawai harus mendapatkan perhatian yang khusus dari pihak kepala disdik jika pemeliharaan pegawai dikelola dengan baik oleh kepala Disdik, maka Pegawaiakan memiliki semangat bekerja, berdisiplin tinggi dan bersikap loyal pada Kantor Dinas Pendidikan

Kabupaten Labuhanbatu .

5. Dan Untuk membina hubungan kerja yang baik tersebut diperlukan adanya kepercayaan (trust) diantara kedua belah pihak. Beberapa penelitian menunjukan bahwa membangun dan mempertahankan trust sangat penting dalam membangun hubungan organisasi atau Instansi.

\section{Saran}

Berdasarkan hasil penelitian yang dilakukan oleh penulis, maka penulis dapat memberikan saran yang sekiranya berguna bagi pembaca dan instansi terkait

1. Peningkatan kerja pada kualitas, orientasi pelayanan dan komitmen. Peningkatan kemampuan pegawai pada kemampuan mengambil keputusannya dan kemampuan menggunakan peralatan modern.

2. Untuk meningkatkan kinerja pegawai perlu ditingkatkan kemampuan pegawai dan motivasi pegawai, kepemimpinan, iklim organisasi dan inisiatip pegawai 


\section{DAFTAR BACAAN}

Hasibuan, 2005,Manajemen Sumber Daya Manusia.PT. Bumi Askara, Edisi revisi, Jakarta.,

Flippo,Edwin B.1984Personnel Management, Sixth Edition. New York:Mc.Graw-Hill Book Company.

Terry R. 1978. Principle of Management, Seventh Edition. Homewood IIilonois, Richsard D. Irwin Inc. 